\title{
SURGICAL TREATMENT OF PERIPHERAL NERVES COMBAT WOUNDS OF THE EXTREMITIES
}

DOI: 10.36740/WLek202103210

\author{
Vitalii I. Tsymbaliuk', Sergii S. Strafun², Ihor B. Tretyak', laroslav V. Tsymbaliuk', Alexander A. Gatskiy', \\ Yuliia V. Tsymbaliuk', Mykhailo M. Tatarchuk ${ }^{1}$ \\ 'STATE INSTITUTION "ROMODANOV NEUROSURGERY INSTITUTE OF THE NATIONAL ACADEMY OF MEDICAL SCIENCES OF UKRAINE", KYIV, UKRAINE \\ 2STATE INSTITUTION“THE INSTITUTE OF TRAUMATOLOGY AND ORTHOPEDICS BY THE NATIONAL ACADEMY OF MEDICAL SCIENCES OF UKRAINE”, KYIV, UKRAINE
}

\begin{abstract}
The aim: Improving the effectiveness of patients' treatment with combat injuries of the peripheral nervous system, which consists in the application and development of new methods of reconstructive interventions, optimizing a set of therapeutic and diagnostic measures for the most effective management of this category of patients with peripheral nerve injury.

Materials and methods: The research is based on the results of surgical treatment of 138 patients with combat injuries of peripheral nerves for the period from 2014 to 2020. The mean age was $33.5 \pm 2.1$ years. Patients were treated for 1 to 11 months after injury (median -8 months). Damage to the sciatic nerve was observed in $26.1 \%$, ulnar - in $20.3 \%$, median - in $18.8 \%$, radial - in $15.9 \%$, tibial - in $10.9 \%$, common peroneal nerve - in $8 \%$ of cases.

Results: It was shown that in all patients was significantly improved the recovery of all nerves. In the period from 9 to 12 months, the degree of recovery of motor function to M0-M2 was observed in 40.6\%, to M3 - in 35.5\%, to M4 - in 16.7\%, to M5 - in 7,2\%. The degree of recovery of sensitivity to S0-S2 was observed in 36.2\%, to S3 - in 42.8\%, to $S 4$ - in $17.4 \%$, to 55 - in $3.6 \%$. Regression of pain syndrome after surgery was observed in $81.2 \%$ of patients.

Conclusions: The results of surgical treatment of peripheral nerves gunshot injury are generally worse than other types of nerve injuries. The best results of surgical treatment of combat trauma of peripheral nerves are obtained in patients with sciatic nerve damage.
\end{abstract}

KEY WORDS: surgery, peripheral nerve injury, combat trauma, electrostimulation

Wiad Lek. 2021;74(3 p.ll):619-624

\section{INTRODUCTION}

Combat injuries of peripheral nerves differ significantly from injuries of peripheral nerves in peacetime in the severity of the lesion, the nature of the restoration processes of the nerve trunks structure and function, require the use of more complex differentiated surgical approaches.

Mine-blast and gunshot wounds to the extremities are an extremely pressing problem in both wartime and peacetime. The main type of damage in wartime is a mine-blast injury, which accounts for about $75 \%$, of which $70 \%$ have limb injuries [1]. Current data from $9 \%$ to $25 \%$ when mine-blast trauma existing damage peripheral nerves (PN) and the actual combat injuries make up 12 to $25 \%$ of all causes damage to the brachial plexus structures [2]. The severity of the patient's injury is determined by the caliber and type of wounding projectile, the presence of combined damage to blood vessels, nerves, bones of the extremities and soft tissues, which are up to $80 \%$ [3].

Gunshot wounds remain one of the most common causes of fractures and the leading cause of disability in the world. According to the Centers for Disease Control, intentional gunshot wounds are the seventh most violent accident in the United States. [4, 5].

That is, this type of injury is not uncommon in peacetime. In the United States, 300,000 people receive gunshot wounds each year, 24,000 of whom die [6].
In the structure of traumatic injuries, injuries of the upper and lower extremities are about $6 \%$, but in terms of disability take first place. It is the damage to the extremities that causes significant both moral and material damage, as patients become incapacitated. According to studies by some scientists [7], gunshot wounds to peripheral nerves in peacetime account for $7.1 \%$ of the total structure of their injuries.

Combat damage to peripheral nerves leads to loss of motor, sensory, autonomic functions of injured limbs, which is also manifested by hyperalgesia, hyperpathy, neuropathic pain and more.

These patients are among the areas of interest of neurosurgeons, neurologists, traumatologists, psychologists and psychiatrists, rehabilitation specialists etc.

Given the current armed conflicts in the world, solving the problem of effective and adequate care for the wounded with combat injuries of peripheral nerves is urgent and necessary.

\section{THE AIM}

Improving the effectiveness of patients' treatment with combat injuries of the peripheral nervous system, which 
consists in the application and development of new methods of reconstructive interventions, optimizing a set of therapeutic and diagnostic measures for the most effective management of this category of patients with peripheral nerve injury.

\section{MATERIALS AND METHODS}

The research is based on the results of surgical treatment of 138 servicemen and civilians with gunshot and mine-explosive injuries of peripheral nerves for the period from 2014 to 2020 . The age of patients ranged from 18 to 62 years, the mean age was $33.5 \pm 2.1$ years $(\mathrm{M} \pm \sigma)$. Male patients predominated $-98.6 \%$, women among patients were only 2 people (1.4\%). Patients were treated for 1 to 11 months after injury (median - 8 months). Damage to the nerves of the upper extremities accounted for $55 \%$ of cases, the lower - $45 \%$. Damage to the sciatic nerve was observed in $26.1 \%$, ulnar - in $20.3 \%$, median - in $18.8 \%$, radial - in $15.9 \%$, tibial - in $10.9 \%$, common peroneal nerve - in $8 \%$ of cases (Fig. 1).

The degree of movement recovery was assessed by the MRC (Medical Research Council) scale from M0 to M5, sensitivity - from S0 to S5 [8].

The severity of the pain syndrome was assessed by the Visual Analogue Scale VAS (1-10) [9].

Approximately 20\% of victims have damage to several nerve trunks, $45 \%$ have severe concomitant lesions of muscles, blood vessels, internal organs.

Among the examined 138 patients, in 83 cases $(60.1 \%)$ partial nerve damage was detected, in 55 (39.9\%) - complete. The causes of nerve damage were: debris (Fig. 2), bullet, mine-explosive injuries, nerve rupture as a result of bone fractures, damage by sharp objects, iatrogenic nerve damage.

Among the etiological factors that caused partial nerve damage, mine-explosive and bullet wounds were most often noted (Fig. 3) - 67 people ( $80.7 \%$ ), less often nerves were injured in fractures of limb bones -7 observations (8.4\%), in 4 cases (4.8\%) there was damage to nerves during the operation, as well as there were harness injuries to the extremities, injuries with sharp objects (metal objects) - 3 cases $(3.6 \%)$, in 2 cases \%) the cause of nerve damage was compression damage to the extremities.

The analysis of short-term and long-term results of treatment of patients with combat trauma of the $\mathrm{PN}$ was performed by assessing motor and sensory function, the severity of pain using a scale assessment and additional objective research methods (neurophysiological and neuroimaging). The neurophysiological included EMG (electromyography) and ENMG (electroneuromyography). Neuroimaging methods - X-ray, CT (computed tomography), MRI (magnetic resonance imaging), ultrasound examination of the extremities.

The neurophysiological complex of preoperative diagnostics consisted of the following methods: ENMG with assessment of motor and sensory functions of peripheral nerves, $\mathrm{F}$ - wave and $\mathrm{H}$ - reflex parameters; Intramuscular
EMG with assessment of spontaneous muscle fiber activity and calculation of motor unit parameters.

Electromyographic studies were performed on a Neuro-MVP Copyright NeuroSoft device (Russian Federation). Stimulation was performed from the cathode (in some cases from the anode) with pulses lasting $0.05 \mathrm{~ms}$, frequency 1 per second, the intensity of stimulation was selected individually, often at the level of 20-35 mV (10$30 \mathrm{~mA}$ ), based on the level at which achieved maximum amplitude of nerve action potential (AP) and muscle AP. They were recorded simultaneously for each stimulus using two lead channels. Deployment speed $10 \mathrm{~ms} /$ division, amplifier sensitivity - from 100 to $2000 \mu \mathrm{V}$ for nerve AP, 100 to $10,000 \mu \mathrm{V}$ - for muscle AP. Frequency pass band from 10 to $10,000 \mathrm{~Hz}$. Averaged 4 responses to calculate each of the AP.

The examination used three main EMG techniques: the study of M-response and the rate of propagation of excitation on the affected and symmetrical nerves, the study of sensory conduction, needle electromyography with analysis of spontaneous muscle fiber activity and study of motor unit potential. Additionally, a modified method of studying the M-response was used in the removal of the needle electrode from the denervated muscle.

Intraoperative diagnostics was performed using a the Miorhythm-021 electrical stimulator (Ukraine, Kyiv). Pulsed current stimulation assessed the ability of the muscles innervated by the studied nerve to contract.

The period of follow-up - $12-18$ months.

Statistics. The analysis of the study results was performed using the package EZR v. 1.35 (R statistical software version 3.4.3, $\mathrm{R}$ Foundation for Statistical Computing, Vienna, Austria) $[10,11]$. In groups with small samples, the following nonparametric methods were used: when comparing changes in rank quantitative traits after treatment, the T-Wilcoxon test was used for related samples; when comparing the results in more than two groups, the Kruskal-Wallis criterion was used, and the Dunn multiple comparison criterion was used to perform pairwise posterior comparisons. The analysis used criteria from the bilateral critical area, the critical level of significance is taken to be equal to 0.05 .

\section{RESULTS}

According to the results of surgical treatment of 138 wounded, there was performed, depending on nerve damage, nerve decompression (neurolysis) (in $72.7 \%$ of cases, including in combination with implantation of electrical stimulation systems), nerve suture (in 19.3\%), and in the case of large defects - nerve grafting with the use of sural nerve (in $8 \%$ of cases) - Fig. 4.

Conditions for surgical treatment of combat injuries of peripheral nerves: intervention by a specialist who has the skills of microsurgical techniques with a thorough knowledge of the topographic anatomy of peripheral nerves, able to provide accurate diagnosis of the nature, degree and level of nerve damage; the presence of an operating microscope; 


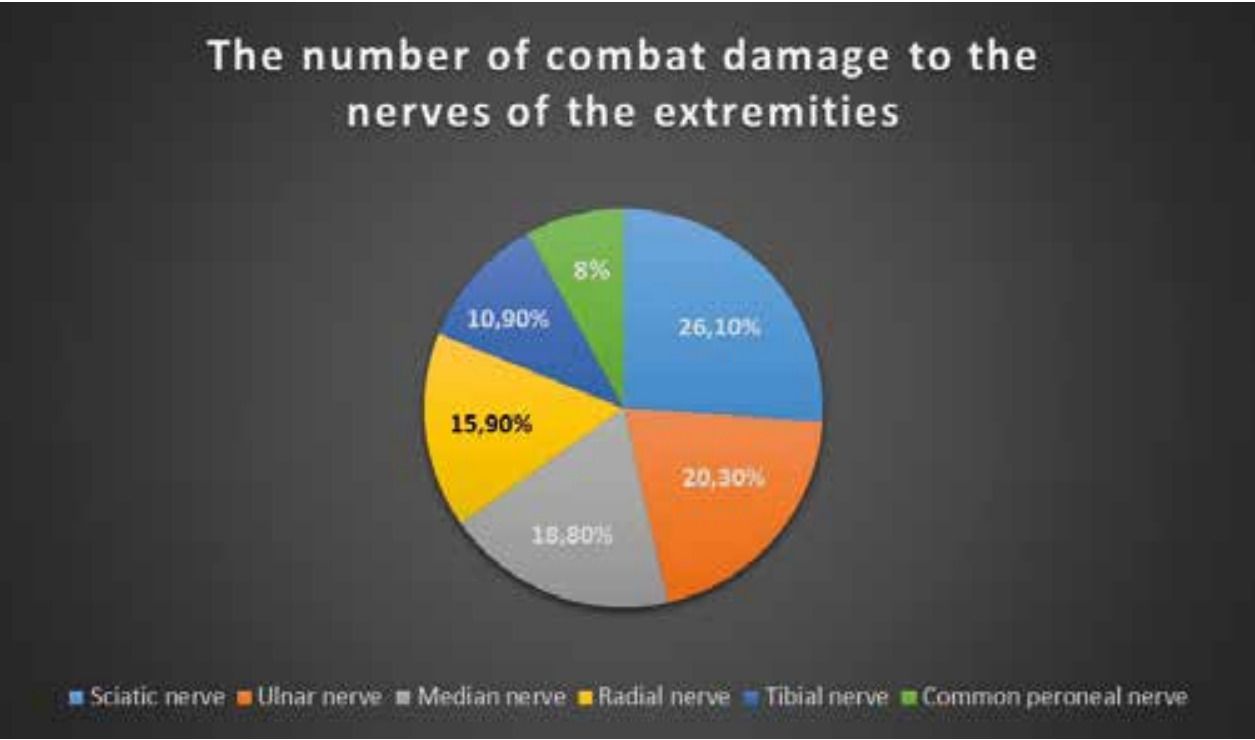

Fig. 1. Distribution diagram of the combat damage frequency to the nerves of the upper and lower extremities

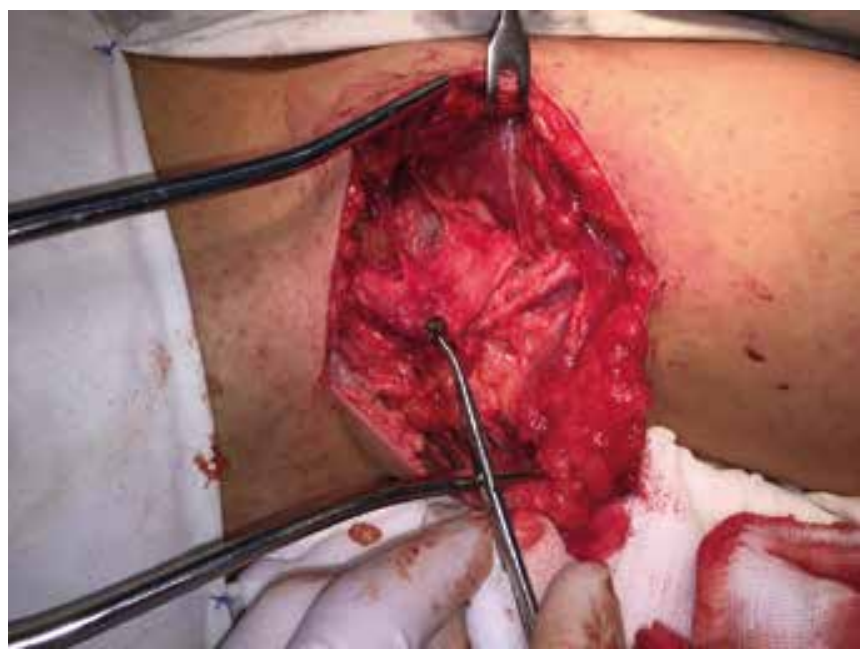

Fig. 2. Removal of a fragment from the tibial nerve

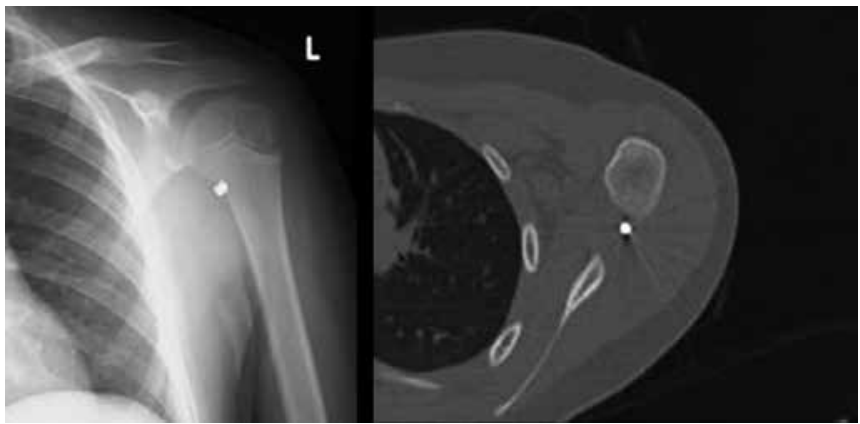

Fig. 3. Bullet damage to the radial nerve in the upper third of the shoulder

availability of microsurgical instruments, suture material, equipment for intraoperative electrodiagnostics; adequate anesthesia.

All surgeries were performed using a microscope (under X 12 optical magnification), appropriate microsurgical instruments, and microsuture material. Evaluated the immediate and long-term results of treatment. The immediate results of treatment were evaluated in the

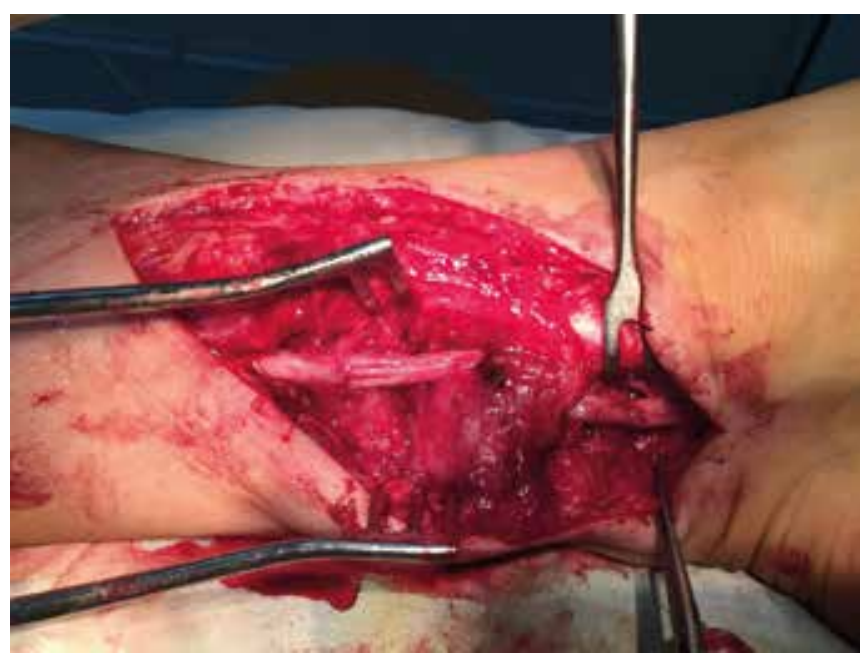

Fig. 4. Tibial nerve grafting

period from 3 to 6 months, long-term - in the period from 9 to 12 months.

The indicators of nerve recovery on the MRC scale to M0-M2, S0-S2 were considered unsatisfactory; satisfactory - up to M3, S3; good - up to M4-M5, S4-S5.

In the period from 3 to 6 months, the degree of recovery of motor function to M0-M2 was observed in $52.3 \%$, to M3 - in $40.6 \%$, to M4 - in 6.5\%, to M5 - in 0,6\%. The degree of recovery of sensitivity to S0-S2 was observed in $45.7 \%$, to $\mathrm{S} 3$ - in $46.8 \%$, to $\mathrm{S} 4$ - in $5 \%$, to S5 - in $2.5 \%$.

In the period from 9 to 12 months, the degree of recovery of motor function to M0-M2 was observed in $40.6 \%$, to M3 - in $35.5 \%$, to M4 - in $16.7 \%$, to M5 - in 7,2\%. The degree of recovery of sensitivity to S0-S2 was observed in $36.2 \%$, to $\mathrm{S} 3$ - in $42.8 \%$, to $\mathrm{S} 4$ - in $17.4 \%$, to S5 - in $3.6 \%$ (Table I).

We also answered the question of whether the treatment rates significantly improved before and after surgery in groups according to the damaged nerve.

In each group we compared the degree of nerve dysfunction on the MRC scale (movements and sensitivity) before and after surgery - in the long term - 9-12 months). 
Table I. Indicators of nerve recovery in 9-12 months.

\begin{tabular}{|c|c|c|c|c|c|c|c|c|c|c|}
\hline \multirow{3}{*}{ Nerves } & \multirow{3}{*}{ Surgery } & \multicolumn{8}{|c|}{ Degree of recovery, points } & \multirow{3}{*}{ Total } \\
\hline & & \multicolumn{4}{|c|}{ Movements } & \multicolumn{4}{|c|}{ Sensitivity } & \\
\hline & & $0-2$ & 3 & 4 & 5 & $0-2$ & 3 & 4 & 5 & \\
\hline \multirow{3}{*}{ Ulnar } & Nerve suture & 6 & 2 & - & - & 5 & 2 & 1 & - & 8 \\
\hline & Nerve grafting & 2 & 3 & - & - & 2 & 3 & - & - & 5 \\
\hline & Nerve decompression & 7 & 2 & 2 & 4 & 4 & 8 & 2 & 1 & 15 \\
\hline \multirow{3}{*}{ Median } & Nerve suture & 5 & 2 & 3 & - & 4 & 4 & 2 & - & 10 \\
\hline & Nerve grafting & & 3 & - & - & & 3 & - & - & 3 \\
\hline & Nerve decompression & 5 & 6 & 2 & - & 4 & 4 & 5 & - & 13 \\
\hline \multirow{3}{*}{ Radial } & Nerve suture & 2 & 4 & - & - & 2 & 4 & - & - & 6 \\
\hline & Nerve grafting & 4 & 3 & - & - & 5 & 2 & - & - & 7 \\
\hline & Nerve decompression & 4 & 2 & 2 & 1 & 2 & 3 & 3 & 1 & 9 \\
\hline \multirow{2}{*}{ Common peroneal } & Nerve suture & - & 2 & 1 & - & - & 2 & 1 & - & 3 \\
\hline & Nerve decompression & 5 & 3 & - & - & 5 & 3 & - & - & 8 \\
\hline \multirow{2}{*}{ Tibial } & Nerve grafting & 2 & 1 & - & - & 2 & 1 & - & - & 3 \\
\hline & Nerve decompression & 6 & 3 & 2 & 1 & 6 & 4 & 2 & - & 12 \\
\hline \multirow{2}{*}{ Sciatic } & Nerve suture & - & 2 & 2 & - & - & 1 & 3 & - & 4 \\
\hline & Nerve decompression & 8 & 11 & 9 & 4 & 9 & 15 & 5 & 3 & 32 \\
\hline \multicolumn{2}{|c|}{ Total } & 56 & 49 & 23 & 10 & 50 & 59 & 24 & 5 & 138 \\
\hline
\end{tabular}

Table II. Pairwise comparisons of treatment results after surgery separately according to the damaged nerve

\begin{tabular}{|c|c|c|c|}
\hline \multirow{2}{*}{ Pair of Variables } & \multicolumn{3}{|c|}{$\begin{array}{c}\text { Wilcoxon Matched Pairs Test } \\
\text { Marked tests are significant at } p<0,05\end{array}$} \\
\hline & Valid & $\mathbf{T}-\mathbf{Z}$ & p-value \\
\hline $\begin{array}{l}\text { Sciatic nerve: } \\
\text { MRC-scale, movements and sensitivity (before surgery) \& MRC- } \\
\text { scale, movements and sensitivity (after 9-12 months post-op) }\end{array}$ & 36 & 0,00 & $<0,001$ \\
\hline $\begin{array}{l}\text { Ulnar nerve: } \\
\text { MRC-scale, movements and sensitivity (before surgery) \& MRC- } \\
\text { scale, movements and sensitivity (after 9-12 months post-op) }\end{array}$ & 28 & 0,00 & $<0,001$ \\
\hline $\begin{array}{l}\text { Median nerve: } \\
\text { MRC-scale, movements and sensitivity (before surgery) \& MRC- } \\
\text { scale, movements and sensitivity (after 9-12 months post-op) }\end{array}$ & 26 & 0,00 & $<0,001$ \\
\hline $\begin{array}{l}\text { Radial nerve: } \\
\text { MRC-scale, movements and sensitivity (before surgery) \& MRC- } \\
\text { scale, movements and sensitivity (after 9-12 months post-op) }\end{array}$ & 22 & 0,00 & $<0,001$ \\
\hline $\begin{array}{l}\text { Tibial nerve: } \\
\text { MRC-scale, movements and sensitivity (before surgery) \& MRC- } \\
\text { scale, movements and sensitivity (after 9-12 months post-op) }\end{array}$ & 15 & 0,00 & $<0,001$ \\
\hline $\begin{array}{l}\text { Common peroneal nerve: } \\
\text { MRC-scale, movements and sensitivity (before surgery) \& MRC- } \\
\text { scale, movements and sensitivity (after } 9-12 \text { months post-op) }\end{array}$ & 11 & 0,00 & 0,004 \\
\hline
\end{tabular}

The analysis was performed using the Wilcoxon Matched Pairs Test, which is used to test two related samples, such as before and after surgery, to determine whether repeated measurements are the same on separate observations (Table II).
The same indicators were obtained for the improvement of motor and sensory function in 5 groups at the level of significance $\mathrm{p}<0.001$ and in 1 group at the level of $\mathrm{p}=0.004$. Thus, we can conclude that in all patients was significantly improved the recovery of all nerves. 
The analysis revealed a statistically significant $(\mathrm{p}<0.05$ by Kruskal-Wallis test) difference in treatment outcomes between the group where the sciatic nerve was damaged and between the groups where other nerves were injured. At the same time, the indicators of motor function on the MRC scale after treatment in all groups were statistically significantly worse ( $\mathrm{p}<0.05$ according to the Dunn's test) than in the group where the sciatic nerve was damaged. Other statistically significant differences in motor function on the MRC scale after treatment between groups (ulnar, median, radial, tibial, common peroneal nerves) were not detected ( $p>0.05$ ) by Dunn's test. Also, no statistically significant differences were obtained between all groups of damaged nerves in terms of recovery of sensitivity on the MRC scale ( $p>0.05$ ) according to the Dunn's test. Thus, the best indicators of recovery of motor function are observed in patients who underwent surgical treatment of the sciatic nerve.

When comparing the recovery of lost nerve function in patients who received only nerve decompression with the methods of nerve decompression and long-term electrical stimulation, statistically significant differences were obtained at the level of $\mathrm{p}<0.05$ by Kruskal-Wallis and $\mathrm{p}<0.05$ by Dunn's test. Thus, we can assume that the use of long-term electrical stimulation gives better results in the restoration of motor and sensory function in patients with combat trauma of peripheral nerves compared with the classical method of nerve decompression.

Regression of pain syndrome after surgery was observed in $81.2 \%$ of patients at the level of evidence using the non-parametric criterion Wilcoxon Matched Pairs Test $(\mathrm{p}<0.05)$. Of these, in $59.4 \%$ of patients, there was a decrease in the manifestations of pain for VAS from 8-10 to 4-5, which can be regarded as a satisfactory result of treatment.

The analyzed data of patients' medical histories during 2014-2020 show that the peculiarities of gunshot wounds of servicemen and civilians are:

- significant predominance of fragmentary lesions (59.8\%) over bullet lesions (14.9\%), injuries of various localizations in $17.5 \%$, thermal lesions in $2.3 \%$, combined injuries - in $5.5 \%$ of cases;

- approximately $1 / 4$ of the victims have damage to several nerve trunks and plexuses;

- $50 \%$ have severe concomitant lesions of muscles, blood vessels, internal organs;

- the presence of more than $90 \%$ of purulent-inflammatory complications;

- the presence of persistent pain (more than $80 \%$, especially in the presence of foreign bodies);

\section{DISCUSSION}

The effectiveness of surgical treatment of peripheral nerves surgical trauma of the extremities is worse compared to classical nerve injury, which is mainly due to the extent of nerve trunk damage, its nature, the presence of intraneural scars, violation of vascular microcirculation in the nerve structure $[12,13]$ due to the existing injury of the main vessels and significant damage to the surrounding soft tissues. The availability of modern equipment and means of microsurgical treatment also has a significant impact on the results of surgical treatment, as well as the level of doctor's training skills.

While the use of microsurgery techniques in the surgical treatment of peripheral nerve damage (including gunshot) is widely represented in the literature $[14,15]$, the use of long-term epineural electrical stimulation to restore nerve function is represented mainly by experimental work [16-19]. Our experience with the use of implantable neurostimulators in clinical practice to restore nerve function after its decompression indicates the prospects of long-term epineural electrical stimulation in the treatment of combat trauma to peripheral nerves.

\section{CONCLUSIONS}

The results of surgical treatment of peripheral nerves gunshot injury are generally worse than other types of nerve injuries.

The best results of surgical treatment of combat trauma of peripheral nerves are obtained in patients with sciatic nerve damage.

The use of long-term electrical stimulation improves the prognosis of treatment of gunshot wounds of peripheral nerves.

\section{REFERENCES}

1. Champion H.R., Holcomb J.B., Lawnick M.M. et al. Improved characterization of combat injury. J Trauma. 2010; 68: 1139-1150.

2. Samadian M., Rezaee 0., Haddadian K. et al. Gunshot injuries to the brachial plexus during wartime. Br J Neurosurg. 2009; 23(2): 165-9. doi: 10.1080/02688690902756686. PubMed PMID:19306172.

3. Guriev S.0., Kukuruz Ya.S., Yalovenko V.A. et al. Analiz dosvidu likuvannia vognepal'nyh poranen' kintsivok [Analysis of the experience of treatment of gunshot wounds of the extremities]. Ekstrena medytsyna: vid nauky do praktyky. 2014;2:25-32. (In Ukrainian).

4. Omid R., Stone M.A., Zalavras C.G. et al. Gunshot Wounds to the Upper Extremity. J Am Acad Orthop Surg. 2019;27(7):e301-e310. doi: 10.5435/ JAAOS-D-17-00676.

5. Centers for Disease Control and Prevention: National Center for Injury Prevention and Control Web-based Injury Statistics Query and Reporting System (WISQARS). 2017. http://www.cdc.gov/ncipc/wisqars. Accessed September 7,

6. Oberlin C., Rantissi M. Gunshot injuries to the nerves. Chir Main. 2011; 30(3): 176-82. doi: 10.1016/j.main.2011.04.010. Epub 2011 May 10. PubMed PMID: 21621447.

7. Pushkar Yu.V. Deyaki aspekty diahnostyky ta khirurhichnoyi taktyky pry vohnepal'nykh poshkodzhennyakh peryferychnykh nerviv verkhnikh ta nyzhnikh kintsivok myrnoho chasu [Some aspects of diagnosis and surgical tactics for gunshot wounds of peripheral nerves of the upper and lower extremities in peacetime]. Byuleten' Ukrayins'koyi Asotsiatsiyi Neyrokhirurhiv. 1999;1(8):14-16. (In Ukrainian).

8. Compston A. Aids to the investigation of peripheral nerve injuries. Medical Research Council: Nerve Injuries Research Committee. His Majesty's Stationery Office: 1942; pp. 48 (iii) and 74 figures and 7 diagrams; with aids to the examination of the peripheral nervous system. By Michael O'Brien for the Guarantors of Brain. Saunders Elsevier: 2010; pp. [8] 64 and 94 Figures. Brain. 2010;133(10):2838-44. doi: 10.1093/brain/awq270. 
9. Thong I.S.K., Jensen M.P., Miró J. et al. The validity of pain intensity measures: what do the NRS, VAS, VRS, and FPS-R measure? Scand J Pain. 2018;18(1):99-107. doi: 10.1515/sjpain-2018-0012. PMID: 29794282.

10. Kanda Y. Investigation of the freely available easy-to-use software 'EZR' for medical statistics. Bone Marrow Transplant. 2013;48:452-458. doi: 10.1038/bmt.2012.244.

11. Gurianov V.G. Posibnyk z biostatystyky. Analiz rezul'tativ medychnykh doslidzhen' u paketi EZR (R-statistics): navchal'nyy posibnyk. K.:Vistka; 2018: 59-78.

12. Strafun S.S., Borzykh N.0., Tsymbaliuk Ya.V. Otsinka efektyvnosti likuvannya poranenykh iz vohnepal'nymy polistrukturnymy ushkodzhennyamy verkhnikh kintsivok [Estimation of the treatment efficacy in the wounded persons with the gun-shot polystructural damages of upper extremities]. Klinichna khirurhiia. 2018;85(7):62-66. doi: 10.26779/2522-1396.2018.07.62. (In Ukrainian).

13. Strafun S.S., Borzykh N.O., Gaiko 0.G. et al. Priorytetni napryamy khirurhichnoho likuvannya poranenykh z ushkodzhennyam peryferychnykh nerviv verkhn'oyi kintsivky pry polistrukturnykh travmakh [Priority areas of surgical treatment of wounded with damage to peripheral nerves of the upper extremity in polystructural injuries]. Trauma. 2018;19(3):85-90. doi: http://dx.doi.org/10.22141/16081706.3.19.2018.136410.(In Ukrainian).

14. Korus L., Ross D.C., Doherty C.D. et al. Nerve transfers and neurotization in peripheral nerve injury, from surgery to rehabilitation. J Neurol Neurosurg Psychiatry. 2016;87(2):188-97. doi: 10.1136/jnnp-2015310420.

15. Dvali L., Mckinnon S. The role of microsurgery in nerve repair and nerve grafting. Hand Clin. 2007;21:73-81.

16. Willand M.P., Nguyen M.A., Borschel G.H. et al. Electrical Stimulation to Promote Peripheral Nerve Regeneration. Neurorehabil Neural Repair. 2016;30(5):490-96. doi: 10.1177/1545968315604399.

17. Gordon T., Chan K.M., Sulaiman 0.A. et al. Accelerating axon growth to overcome limitations in functional recovery after peripheral nerve injury. Neurosurgery. 2009; 65 (4):A132-A144. doi:10.1227/01. NEU.0000335650.09473.D3.

18. Koo J., MacEwan M.R., Kang S.K. et al. Wireless bioresorbable electronic system enables sustained non-pharmacological neuroregenerative therapy. Nature Medicine. 2018. D0I: 10.1038/s41591-018-0196-2.

19. Tretiakova A.I., Kovalenko I.V., Tretiakov R.A. et al. Diagnostics and Treatment of Proximal Tunnel Neuropathies of the Upper Limbs. Novosti Khirurgii. 2020; 28 (1): 62-73.
The work was performed in accordance with the current research of the department of Restorative Neurosurgery, State Institution "Romodanov Neurosurgery Institute of the National Academy of Medical Sciences of Ukraine”, Kyiv, Ukraine on the topic: "To improve methods of differentiated treatment of patients with pain syndromes caused by combat injuries of the peripheral nervous system» (2019-2021, state registration number 0119U000112). The National Academy of Medical Sciences of Ukraine is the institution that finances the research.

\section{ORCID and contributionship:}

Vitalii I. Tsymbaliuk: 0000-0003-3608-9679 A,E,F

Sergii S. Strafun: 0000-0001-8178-9290 B,E,F

Ihor B. Tretyak: 0000-0003-0977-7062 ${ }^{B, F}$

Iaroslav V. Tsymbaliuk: 0000-0002-8746-0944 A,B,C,D

Alexander A. Gatskiy: 0000-0002-2212-2143 A,B,C

Yuliia V. Tsymbaliuk: 0000-0002-0025-3505 E,F

Mykhailo M. Tatarchuk: 0000-0002-2297-2527 ${ }^{A, B}$

\section{Conflict of interest:}

The Authors declare no conflict of interest.

\section{CORRESPONDING AUTHOR laroslav V. Tsymbaliuk}

Romodanov Neurosurgery Institute of the National Academy of Medical Sciences of Ukraine 32 Platona Maiborody str., 04050 Kyiv, Ukraine tel: +380937266066 e-mail: yaroslav.neuro@gmail.com

Received: 12.11 .2020

Accepted: 06.03 .2021

A - Work concept and design, B - Data collection and analysis, C - Responsibility for statistical analysis, D-Writing the article, $\mathbf{E}$-Critical review, $\mathbf{F}$ - Final approval of the article 